\title{
Does FDI in China Displace Foreign Jobs in Asia?
}

\author{
Jordi Paniagua ${ }^{1}$ \\ ${ }^{1}$ Faculty of Economics and Business, Catholic University of Valencia “San Vicente Mártir”, Valencia, Spain \\ Correspondence: Jordi Paniagua, Faculty of Economics and Business, Catholic University of Valencia "San \\ Vicente Mártir”, C/. Corona 34, 46003 Valencia, Spain. Tel: 34-96-3637412. E-mail: Jordi.paniagua@ucv.es
}

Received: September 28, 2014

Accepted: September 30, 2014

Online Published: October 25, 2014

doi:10.5539/ijef.v6n11p52

URL: http://dx.doi.org/10.5539/ijef.v6n11p52

\begin{abstract}
This paper studies the China effect from a novel perspective. We focus on the effect of FDI in China on foreign employment flows in the rest of Asia. The concentration of FDI in China may divert employment from similar surrounding countries. Offsetting this negative effect, MNE activities might spillover to neighboring countries along the foreign production chain. Therefore, the effect of global FDI champions is uncertain. Most studies on this issue focus on trade and FDI inflows. The China effect on other aspects of international production, like employment, remains largely unknown. The contributions of this paper are twofold. First, we enhance the estimation of the China effect with recent econometrics developments in international economics. Second, we study foreign employment, which has been overlooked by the specialized literature. We determine empirically this effect on a set 25 Asiatic countries during 2003-2009. Results suggest a mild job diversion in Asia.
\end{abstract}

Keywords: foreign direct investment, FDI, foreign employment, jobs, multinational enterprise, MNE, spillover, diversion, China, Asia

\section{Introduction}

The goal of this paper is to analyze the effect of China's championship over foreign direct investment (FDI) on its Asiatic neighbors. In the late 1990s and early 2000s, neighbor countries feared that China's FDI magnetism might divert investments from countries with similar factor endowments and production costs in a low-cost-skilled-technology environment. Politicians, academics and policymakers shared distress observing China's rapid economic growth: "Everyone is feeling the pinch because the amount of FDIs [sic] has shrunk and then, a lot of that is going to China." (Prime Minister of Malaysia Mahathir, Straits Times, 21 September 2002, quoted in McKibbin and Woo 2003 p. 16 and Eichengreen and Tong 2007, p. 154). Analyses by the IMF (International Monetary Fund, 2002, 2004) warned that China's full integration into the global economy could harm developing-country destinations.

Offsetting this threat were the promises of China's growth would increase both domestic demand and the potential for collaborating in the segments of the international production chain. This contending view argued that individual countries can maximize their gains from Chinese FDI by making their own economies more flexible (The Economist, 2004). Additionally, China's opening up of its domestic market for imports, provided great opportunities for the regional economies (Abeysinghe \& Lu, 2003).

From a theoretical perspective it is unfeasible to assess ex-ante whether China's imports and productive complementarities counterweigh its diversion menace. The dynamic complexity of the worldwide Multinational Enterprises (MNE) operations renders an uncertain outcome (Note 1). Among other factors, the result depends on many factors such as wages, domestic demand, industrial depth, skill pools, the willingness of governments (Lall \& Albaladejo, 2004). Henceforth, empirical academic studies flourished to respond to the question "Has China displaced FDI in Asia?" offering mixed results.

The study of geographical displacement is deeply related with the international production location field. Cantwell (2009, p. 35) identifies the "apparent paradox" between Thomas Friedman's (2007) flat world and the increasing importance of local clusters which attract investment, knowledge and innovation across borders (Breschi \& Malerba, 2001; Dunning, 2009). Porter (1994) attempted to resolve the location of international production puzzle by distinguishing between standardized intermediate product inputs and knowledge creation and innovation activities. Standard supplies were supposedly available to any firm, reducing the competitive advantage of local proximity. However, innovative activities largely depend on physical proximity, clustering 
and concentrating economic activity on a few sites. Therefore, according to Porter's view, MNE activities which can easily be replicated at any other site will be subject to FDI diversion. However, FDI can also be created in neighboring countries which offer better profits in a tier production scheme. For instance, a country like China might specialize in high skilled investment and induce complementary lowed skilled investment in neighbor countries.

The study of displacement is deeply related and motivated by the appearance of new players in the economic arena. These countries share some economic trends, such as high GDP growth, trade expansion and large volumes of trade or FDI inward flows, as shown in the following tables. China is the premier recipient of foreign direct investment globally (World Bank, 2013). China's market and population size, communications infrastructure and low labor costs, among others are usually pin-pointed as the main reasons for this success. China's FDI and its impact on the Asian and world's economy have been thoroughly examined in the specialized literature under various perspectives. The question between domestic crowding out due to foreign investment in developing economies is a recurrent theme (Rothgeb, 1990; Moran, 1998; Agosin \& Machado, 2005; Moran, Graham, \& Blomström, 2005) along with the promotion of development due to FDI (Crenshaw, 1991; Moran et al., 2005; Rugman \& Doh, 2008). Various authors study the determinants of FDI in China (Hong \& Chen, 2001); the relationship between FDI and growth in China (Saab, 2007; Wei, 2008); and the relationship between FDI and regional innovation $(\mathrm{Fu}, 2008)$.

However, the effect of this rapid growth on neighbor countries may vary regionally. Through the study of the effect of these new players on their neighbors and competitors, a better understanding of the world's new tilt is achieved. The norm has been to analyze the effect of FDI in a particular country, or group of countries, or even at regional level. Scholarly work regarding the effect of China on Asia focuses mainly in trade studies for Asia, offering mixed results (see, among others, Ahearne et al., 2003; Zhou \& Lall, 2005; Eichengreen, Rhee, \& Tong, 2007; Greenaway, Mahabir, \& Milner, 2008; Lall \& Albaladejo, 2004). Researchesrs have also studied the impact of China on other regions like Latin America (Chantasasawat, Fung, Iizaka, \& Siu, 2004; Cravino, Lederman, \& Olarreaga, 2006; Garcia-Herrero \& Santabárbara, 2007; Jenkins, Peters, \& Moreira, 2008) and Europe (Resmini \& Siedschlag, 2008). Fewer studies consider how China's attraction for FDI is affecting FDI flows to other regions. Table 1 presents a summary of the main contributions regarding the China effect.

Table 1. Scholarly contributions to the China effect (trade and FDI)

\begin{tabular}{|c|c|c|c|}
\hline Authors & Focus & Result & Method/sample \\
\hline $\begin{array}{l}\text { Greenaway, Mahabir and Milner } \\
(2008)\end{array}$ & Trade diversion due to China & Mild Trade diversion in Asia & $\begin{array}{l}\text { Gravity Model. } \\
\text { 1990-2003 OLS }\end{array}$ \\
\hline $\begin{array}{l}\text { Ahearne, Fernald, Loungani, \& } \\
\text { Schindler (2003) }\end{array}$ & Trade diversion due to China & Trade creation in Asia & $\begin{array}{l}\text { Panel Vector Autoregresion } \\
1981-2001\end{array}$ \\
\hline Zhou \& Lall (2005) & FDI displacement due to China & FDI creation in Asia & $\begin{array}{l}\text { Panel data OLS } \\
1986-2001\end{array}$ \\
\hline
\end{tabular}

In particular, we find five notable econometric approaches. All of them use a variable to capture the "China effect" within a set of common FDI regressors. This variable captures the gross FDI flows into China, usually expressed in logarithmic terms. The first attempt starts with Zhou and Lall (2005), who use Ordinary Least Squares (OLS) random and fixed effects models to study the China effect on 8 Asian economies. Their results suggest that China raised rather than diverted such investment into neighbouring economies. Morover, Mercereau (2005) suggests that the use logarithmic specification is inappropriate since it measures the effect in rates of change rather than in levels. This insight is relevant, since it also compatible with variables with zeros. Mercereau (2005) uses OLS regressions on a dataset of 14 countries during 1984-2002 with a fixed effects model and dynamic panel. The author finds evidence of FDI crowding out only for two countries. Using a similar approach (with a logarithmic variable) Wang, Wei, and Liu (2007) find mixed effects depending on countries examined (nine in total).

Chantasasawat et al. (2008) consider that FDI in Asia and China are simultaneously determined and use a two-stage least squares to measure the China effect on FDI inflows to 8 Asian Economies 1985-2000. The 
authors obtain a mild positive result. Eichengreen and Tong (2006; 2007) are credited as the most influential reference on the subject of FDI displacement. Using unidirectional bilateral FDI flows as the dependent variable, the authors find evidence to support FDI creation in Asia due to FDI in China, as if producers in these economies belong to a common supply.

However, the use of OLS in these previous studies prevents any possible treatment of self-selection bias due to firm heterogeneity. The log-linearized form prevents estimating data with zeros in the dependent variables as the $\log$ of zero is not defined. The appearance of zeros in a bilateral gravity dataset is generally attributed to firm heterogeneity (Anderson, 2011). Heterogeneous firms decide to export, invest abroad or serve their domestic market as a function of their productivity (Helpman, 2006; Helpman, Melitz, \& Yeaple, 2004). Hence, zeros signal which firms stay under a certain productivity threshold. For example, a zero-valued observation in an aggregate bilateral FDI dataset means that not a single firm from home country $i$ surpassed the productivity threshold to invest in host country $j$. By obviating zeros, estimates incur in a self-selection bias problem, since the sample considers only the most productive firms. Some authors have recently addressed this issue (Davies \& Kristjánsdóttir, 2010; Helpman, Melitz, \& Rubinstein, 2008; Silva \& Tenreyro, 2006).

Moreover, the existing literature on the FDI China effect considers only the capital investment displacement and not its influence on the countries' economy. A growing set of literature has recently highlighted the importance of the employment created by FDI in the host. Paniagua and Sapena (2013) frame the MNE's employees in a host country as foreign knowledge brokers who transmit knowledge from the source to the host country. They are able to quantify the influence of foreign employment on the host's political, corporate and institutional system. Paniagua and Sapena (2014b) integrate FDI jobs in a gravity equation and conclude that foreign employment has influences the host's democratic and legal system. Paniagua and Sapena (2014a) develop a model that explains how foreign employment is affected by credit constraints that result from the recession that started in 2007.

This paper fills these two gaps in the literature: First, we focus our attention on the China effect on foreign employment in Asiatic countries. Second, we estimate the China effect with a technique compatible with zeros and, therefore, robust to the self-selection bias. We thus contribute to a better understanding on the real influence of China on its Asian peers.

\section{Method and Data}

We consider a classical foreign job market, where employment depends on capital invested and salaries (Arellano \& Bond, 1991; Paniagua \& Sapena, 2013; Seyf, 2000). In particular, we estimate the non-linear equation to measure the China effect:

$$
j o b s_{i j t}=\exp \left(\beta_{1} \ln F D I_{i j t}+\beta_{2} \ln F D I_{i j t} * Z_{i c t}+\beta_{3} \ln w_{i t}+\beta_{4} \ln w_{j t}+\lambda_{i}+\lambda_{j}+\lambda_{t}\right)+\varepsilon_{i j t}
$$

where $j o b s_{i j t}$ are the job count created by MNEs from country $i$ in country $j$ during year $t$; FDI is the aggregate value of capital invested by MNEs in creating a greenfield affiliate in Asia (measured in constant US dollars, base year 2000); $Z$ is a dummy variable set to 1 if country $i$ invests in China $(c)$ in year $t ; w$ is the annual average wage in constant US dollars; $\lambda$ stands for a full set of country and year fixed effects to control for third country effects (Anderson \& Van Wincoop, 2003); lastly $\varepsilon$ is an stochastic error term.

In line with other FDI empirical studies (Berden, Bergstrand, \& Etten, 2014; Bergstrand, Larch, \& Yotov, 2013; Kleinert \& Toubal, 2010), we estimate equation (1) with the Poisson pseudo-maximum likelihood (PPML) estimator similar to that proposed by Silva and Tenreyro (2006). PPML offers consistent estimates of data with zeroes since this estimator does not require a log-linearization of the variables and it prevents heteroskadiscity in the error term. PPML has been previously applied to empirical studies of foreign employment (Paniagua \& Sapena, 2013, 2014a, 2014b).

The estimation of the China effect follows partially Eichengreen and Tong (2007). First, we identify the set of source countries that have invested in Asia and in China. Table 1 shows the list of source and destination countries involved in the analysis. However, rather than measuring the level of investment, we focus on the decision to invest or not in China. Thus, we construct a dummy variable $\mathrm{Z}$ to capture this effect. The estimated coefficient of the interaction of this variable with the FDI in Asiatic countries measures the differential the diversion effect of the intention to engage in FDI with China. Previous work on the China effect has neglected the effect of the extensive margin. However, most of the growth of FDI and trade flows comes through the increase in the number of firms (Felbermayr \& Kohler, 2006). The China effect measured in levels captures incidence of FDI volume, but not the FDI intention. Consequently, previous estimates where not taking into account the creation of new linkages through the extensive margin. Furthermore, the probability to engage in FDI is different from the volume of FDI (Helpman et al., 2008). Therefore, we should not be concerned with endogeneity issues. 
Table 1. List of countries

\begin{tabular}{ll}
\hline Destination & $\begin{array}{l}\text { Afghanistan, Armenia, Azerbaijan, Bangladesh, Bhutan, Cambodia, Georgia, India, Indonesia, Japan, Kazakhstan, } \\
\text { Kyrgyzstan, Laos, Malaysia, Mongolia, Pakistan, Philippines, Singapore, South Korea, Sri Lanka, Tajikistan, Thailand, } \\
\text { Turkmenistan, Uzbekistan, Vietnam }\end{array}$ \\
\hline Source & Algeria, Angola, Argentina, Australia, Austria, Bahamas, Bahrain, Belarus, Belgium, Bermuda, Brazil, Bulgaria, Canada, \\
& Chile, Colombia, Costa Rica, Croatia, Cyprus, Czech Republic, Denmark, Dominican Republic, Egypt, Estonia, Ethiopia, \\
& Fiji, Finland, Germany, France, French Polynesia, Ghana, Greece, Guatemala, Hungary, Iceland, Iran, Iraq, Ireland, Israel, \\
& Italy, Jordan, Kenya, Kuwait, Latvia, Lebanon, Libya, Lithuania, Luxembourg, Macau, Malta, Mauritius, Mexico, \\
& Morocco, Netherlands, New Zealand, Nigeria, Norway, Oman, Panama, Papua New Guinea, Peru, Poland, Portugal, Qatar, \\
& Romania, Russia, Rwanda, Saudi Arabia, Serbia, Slovak Republic, Slovenia, South Africa, Spain, Sudan, Swaziland, \\
& Sweden, Switzerland, Syria, Tunisia, Turkey, Uganda, UK, Ukraine, United Arab Emirates, United States, Uruguay, \\
& Venezuela, Yemen, Zambia, Zimbabwe
\end{tabular}

The data come from Paniagua and Sapena (2013). The time span of the sample is 2003-2009. Hence, we provide an updated estimation of the China effect since the most relevant studies end their time period in 2003. Table 2 shows the descriptive statistics for the subsample of countries that we study.

Table 2. Descriptive statistics

\begin{tabular}{lccc}
\hline Variable & Label & Mean & Standard Deviation \\
\hline Employment & $j o b s_{i j t}$ & 967 & 331.1 \\
FDI & $\operatorname{lnFDI_{ijt}}$ & 19.23 & 1.86 \\
Home wages & $\ln w_{i t}$ & 5.49 & 2.23 \\
Host wages & $\ln w_{j t}$ & 7.57 & 1.83 \\
China Dummy & $Z_{i c t}$ & 0.87 & 0.34 \\
\hline
\end{tabular}

\section{Results and Discussion}

The results reported in Table 3 indicate that our specification fits well the data, explaining more than $92 \%$ of the FDI job variation. The first two columns contain the results of an OLS benchmark and the last two our preferred PPML estimation. In addition to our baseline specification with country fixed effects (CFE), we introduce a set of regressions with country pair fixed effects (CPFE) to control for any unobserved heterogeneity at the country pair level. Overall, we observe that China's inward FDI has a negative effect on Asian employment.

The OLS-CFE results in column 1 show that raising FDI by $1 \%$ would increase foreign jobs by $0.35 \%$. However, wages at the home country seem to be the main driver of foreign employment. China has no significant effect on Asia's FDI jobs. The coefficient of the interaction is not significant to any standard level. The results point, therefore, that foreign employment is mainly driven by labor costs. A point increase in source countries' salaries increases $1.18 \%$ the jobs offered by the country's MNE in Asiatic destinations. The results obtained for home wages, however, are counter-intuitive. We would expect a negative or non-significant coefficient for host's country wages. The estimated coefficient is, nonetheless positive. This result confirms our initial assumption that OLS estimations are biased. The OLS-CPFE in column 2 does not resolve this issue and invites us to focus our attention in the next two columns.

Column 3 reports our preferred specification as it contains the PPML-CFE estimates of equation (1). The estimates of foreign capital and home wages are consistent and with the expected signs. Host wages have no effect on foreign employment, which is a result more closely bound to economic intuition than a positive effect (as in columns 1 and 2). Furthermore, we observe a negative China effect on foreign employment in Asia. Foreign investment in Asia stimulates foreign jobs in $0.37 \%$. However, when MNEs also invest in china, this effect drops to $0.37-0.122=0.25 \%$. This result suggests a mild diversion of foreign employment in Asia. The effect on employment of the control group (MNEs who invest Asia but no in China) is greater than the group of MNEs who invest both in Asia and in China. 
Table 3. Results

\begin{tabular}{|c|c|c|c|c|}
\hline & $(1)$ & $(2)$ & (3) & $(4)$ \\
\hline \multirow{3}{*}{$\ln F D I_{i j t}$} & OLS-CFE & OLS-CPFE & PPML-CFE & PML-CPFE \\
\hline & $0.350 * * *$ & $0.345 * * *$ & $0.372 * * *$ & $0.241 * * *$ \\
\hline & $(0.07)$ & $(0.07)$ & $(0.07)$ & $(0.07)$ \\
\hline \multirow[t]{2}{*}{$\ln F D I_{i j t} * Z_{i c t}$} & -0.0463 & -0.0456 & $-0.122 * * *$ & $-0.0796 * * *$ \\
\hline & $(0.03)$ & $(0.03)$ & $(0.02)$ & $(0.02)$ \\
\hline \multirow[t]{2}{*}{$\ln w_{i t}$} & $1.183^{* *}$ & $1.177 * *$ & $1.875^{* * *}$ & 1.098 \\
\hline & $(0.5)$ & $(0.55)$ & $(0.72)$ & $(0.80)$ \\
\hline \multirow[t]{2}{*}{$\ln w_{j t}$} & $0.765 * * *$ & $0.754 * * *$ & 0.172 & 0.152 \\
\hline & $(0.27)$ & $(0.27)$ & $(0.23)$ & $(0.24)$ \\
\hline Observations & 527 & 527 & 578 & 578 \\
\hline$R^{2}$ & 0.54 & 0.54 & 0.92 & - \\
\hline Year FE & Yes & Yes & Yes & Yes \\
\hline Country FE & Yes & & Yes & \\
\hline Country Pair FE & & Yes & & Yes \\
\hline
\end{tabular}

Note. Standard errors in parentheses; * $\mathrm{p}<0.10, * * \mathrm{p}<0.05, * * * \mathrm{p}<0.01$

The China effect is robust to unobserved heterogeneity at the country pair level. The PPML-CPFE results reported in column 4 show that although the effect has been reduced in magnitude it is still negative and significant to the $1 \%$ level.

\section{Conclusions}

This paper presents a new approach to the China effect. We study the incidence of FDI inflows into China on the foreign employment in Asia. This article, therefore, sheds light on how FDI diversion affects directly local economies. Our estimation profits from recent developments in the econometrics of international economics. We control for self-selection bias, third country effects or multilateral resistance, unobserved heterogeneity and endogeneity. Our empirical technique, therefore, resolves issues of previous studies on this area.

Our results suggest that FDI into China results in mild job attrition in Asia. FDI has a positive influence on job creation in the host and has triggered local policies to attract foreign investment. This positive effect is hampered by China's championship on FDI. The FDI-employment link is reduced by $32 \%$ on average in Asia when MNEs have interests in China.

A priority of today's policymakers is employment and economic growth. Consequently FDI is in the spotlight and occupies the policy agenda of many countries. Our research paves the path to policies which take into account the effect of big competitors like China. The economic downturn in the west might be an opportunity for the rest Asia. New European and American companies, escaping from depressed demands in their countries, might seek opportunities in Asia. Policies aimed to track these companies before they consider China could boost employment in Asian countries.

Our research does have certain limitations, many of which are an invitation to further studies. Although findings are robust across many countries, the relationships might be less applicable to specific destinations or industries. Subsequent studies could inspect the effect on each individual country or group of countries. Additionally, our methodology does not consider contingent factors such as firm size. The results may, therefore, show some bias towards larger MNE and be less applicable to small and medium-sized firms. Future studies that test the validity of our results on smaller MNE are certainly encouraged.

Finally, the main contribution of this paper is to study the China effect on the Asia's foreign jobs. Our methodology can be easily generalized (e.g., Brazil in South America; Russia in Eastern Europe or India in South East Asia). Future studies could capture the effect of local FDI champions in other regions.

\section{References}

Abeysinghe, T., \& Lu, D. (2003). China as an economic powerhouse: Implications on its neighbors. China Economic Review, 14(2), 164-185. http://dx.doi.org/10.1016/s1043-951x(03)00017-8

Agosin, M. R., \& Machado, R. (2005). Foreign Investment in Developing Countries: Does it Crowd in Domestic Investment? Oxford Development Studies, 33(2), 149-162. http://dx.doi.org/10.1080/13600810500137749 
Ahearne, A. G., Fernald, J. G., Loungani, P., \& Schindler, J. W. (2003). China and Emerging Asia: Comrades or Competitors? Seoul Journal of Economics, 16(2), 183-214. http://dx.doi.org/10.2139/ssrn.484503

Anderson, J. E. (2011). The Gravity Model. Annual Review of Economics, 3, $133-160$. http://dx.doi.org/10.3386/w16576

Anderson, J. E., \& Van Wincoop, E. (2003). Gravity with gravitas: a solution to the border puzzle. The American Economic Review, 93(1), 170-192. http://dx.doi.org/10.1257/000282803321455214

Arellano, M., \& Bond, S. (1991). Some tests of specification for panel data: Monte Carlo evidence and an application to employment equations. The Review of Economic Studies, 58(2), 277. http://dx.doi.org/10.2307/2297968

Berden, K., Bergstrand, J. H., \& Etten, E. (2014). Governance and Globalisation. The World Economy, 37(3), 353-386. http://dx.doi.org/10.1111/twec.12135

Bergstrand, J. H., Larch, M., \& Yotov, Y. V. (2013). Economic Integration Agreements, Border Effects, and Distance Elasticities in the Gravity Equation. Working Paper, University of Notre Dame.

Chantasasawat, B., Fung, K. C., Iizaka, H., \& Siu, A. (2004). Foreign Direct Investment in East Asia and Latin America: Is there a People's Republic of China Effect? Asian Development Bank Institute Working Paper No. 66. Retrieved from http://www.adbi.org/files/2006.05.rp66.fdi.prc.effect.pdf

Chantasasawat, B., Fung, K. C., Iizaka, H., \& Siu, A. (2008). Foreign Direct Investment in China and East Asia. In B. M. Fleisher, N. C. Hope, A. Alves Pena, \& D. T. Yang (Eds.), Policy Reform and Chinese Markets: Progress and Challenges. Cheltenham, UK: Edward Elgar Publishing.

Cravino, J., Lederman, D., \& Olarreaga, M. (2006). Foreign direct investment in Latin America during the emergence of China and India: stylized facts. Policy Reasearch Working Paper, World Bank, Washington DC. http://dx.doi.org/10.1596/1813-9450-4360

Crenshaw, E. (1991). Foreign Investment as a Dependent Variable: Determinants of Foreign Investment and Capital Penetration in Developing Nations, 1967-1978. Social Forces, 69(4), 1169-1182. http://dx.doi.org/10.2307/2579307

Davies, R. B., \& Kristjánsdóttir, H. (2010). Fixed Costs, Foreign Direct Investment, and Gravity with Zeros. Review of International Economics, 18(1), 47-62. http://dx.doi.org/10.1111/j.1467-9396.2009.00864.X

Eichengreen, B., Rhee, Y., \& Tong, H. (2007). China and the exports of other Asian countries. Review of World Economics, 143(2), 201-226. http://dx.doi.org/10.1007/s10290-007-0105-0

Eichengreen, B., \& Tong, H. (2006). Fear of China. Journal of Asian Economics, 17(2), $226-240$. http://dx.doi.org/10.1007/s10290-007-0105-0

Eichengreen, B., \& Tong, H. (2007). Is China's FDI coming at the expense of other countries? Journal of the Japanese and International Economies, 21(2), 153-172. http://dx.doi.org/10.1016/j.jjie.2006.07.001

Felbermayr, G. J., \& Kohler, W. (2006). Exploring the intensive and extensive margins of world trade. Review of World Economics, 142(4), 642-674. http://dx.doi.org/10.1007/s10290-006-0087-3

$\mathrm{Fu}, \mathrm{X}$. (2008). Foreign direct investment, absorptive capacity and regional innovation capabilities: Evidence from China. Oxford Development Studies, 36(1), 89-110. http://dx.doi.org/10.1080/13600810701848193

Garcia-Herrero, A., \& Santabárbara, D. (2007). Does China have an impact on foreign direct investment to Latin America? China Economic Review, 18(3), 266-286. http://dx.doi.org/10.1016/j.chieco.2007.02.005

Greenaway, D., Mahabir, A., \& Milner, C. (2008). Has China displaced other Asian countries' exports? China Economic Review, 19(2), 152-169. http://dx.doi.org/10.1016/j.chieco.2007.11.002

Helpman, E. (2006). Trade, FDI, and the Organization of Firms. Journal of Economic Literature, 44(3), 589-630. http://dx.doi.org/10.1257/jel.44.3.589

Helpman, E., Melitz, M., \& Rubinstein, Y. (2008). Estimating Trade Flows: Trading Partners and Trading Volumes. Quarterly Journal of Economics, 123(2), 441-487. http://dx.doi.org/10.1162/qjec.2008.123.2.441

Helpman, E., Melitz, M., \& Yeaple, S. R. (2004). Export versus FDI with heterogeneous firms. American Economic Review, 94(1), 300-316. http://dx.doi.org/10.1257/000282804322970814 
Hong, M., \& Chen, L. S. (2001). Quantitative and dynamic analysis of the OLI variables determining FDI in China. Review of Urban and Regional Development Studies, 13(2), $163-172$. http://dx.doi.org/10.1111/1467-940x.00038

Ianchovichina, E., \& Walmsley, T. (2005). Impact of China's WTO Accession on East Asia. Contemporary Economic Policy, 23(2), 261-277. http://dx.doi.org/10.1093/cep/byi020

IMF (International Monetary Fund). (2002). Foreign Direct Investment in China What Do We Need To Know? Transcript of an Economic Forum (2 May). Retrieved from https://www.imf.org/External/NP/EXR/ECForums/2002/050202.htm

IMF (International Monetary Fund). (2004). China's emergence and its impact on the global economy. World Economic Outlook (April). Retrieved from https://www.imf.org/external/pubs/ft/weo/2004/01/pdf/chapter2.pdf

Jenkins, R., Peters, E. D., \& Moreira, M. M. (2008). The impact of China on Latin America and the Caribbean. World Development, 36(2), 235-253. http://dx.doi.org/10.1016/j.worlddev.2007.06.012

Kleinert, J., \& Toubal, F. (2010). Gravity for FDI. Review of International Economics, 18(1), 1-13. http://dx.doi.org/10.1111/j.1467-9396.2009.00869.x

Lall, S., \& Albaladejo, M. (2004). China's Competitive Performance: A Threat to East Asian Manufactured Exports? World Development, 32(9), 1441-1466. http://dx.doi.org/10.1016/j.worlddev.2004.03.006

McKibbin, W. J., \& Woo, W. T. (2003). The Consequences of China's WTO Accession for Its Neighbors*. Asian Economic Papers, 2(2), 1-38. http://dx.doi.org/10.1162/153535103772624772

Mercereau, B. (2005). FDI Flows to Asia: Did the Dragon Crowd Out the Tigers? IMF Working Paper No. 05/189. http://dx.doi.org/10.5089/9781451862089.001

Moran, T. H. (1998). Foreign direct investment and development: the new policy agenda for developing countries and economies in transition. Washington, D.C.: Peterson Institute.

Moran, T. H., Graham, E. M., \& Blomström, M. (2005). Does foreign direct investment promote development? Washington, D.C.: Peterson Institute.

Paniagua, J., \& Sapena, J. (2013). The ethics of foreign knowledge brokers: a conceptual and empirical $\begin{array}{lllll}\text { framework. } & \text { European } & \text { J. International } & \text { Management, } & 7(3),\end{array}$ http://dx.doi.org/10.1504/ejim.2013.054329

Paniagua, J., \& Sapena, J. (2014a). Do credit constraints reduce foreign jobs? A note on foreign direct employment. Applied Economics Letters. http://dx.doi.org/10.1080/13504851.2014.934420

Paniagua, J., \& Sapena, J. (2014b). Is FDI doing good? A golden rule for FDI ethics. Journal of Business Research, 67(5), 807-812. http://dx.doi.org/10.1016/j.jbusres.2013.11.049

Resmini, L., \& Siedschlag, I. (2008). Is FDI into China Crowding Out FDI into the European Union? DYNREG Working Papers. Retrieved from http://econpapers.repec.org/paper/esrwpaper/dynreg25.htm

Rothgeb, J. M. (1990). Foreign-Investment and the Decapitalization of Underdeveloped Host Countries. Social Science Journal, 27(4), 457-473. http://dx.doi.org/10.1016/0362-3319(90)90018-f

Rugman, A. M., \& Doh, J. P. (2008). Multinationals and Development. New Haven: Yale Univ Press. http://dx.doi.org/10.12987/yale/9780300115611.001.0001

Saab, G. (2007). A Study of Financial Development, FDI and Growth in the GCC Area. Competition Forum, 5(1), 53-58. $\quad$ Retrieved from http://www.questia.com/library/journal/1P3-1390635421/a-study-of-financial-development-fdi-and-growth -in

Seyf, A. (2000). Can more FDI solve the problem of unemployment in the EU? A short note. Applied Economics Letters, 7(2), 125-128. http://dx.doi.org/10.1080/135048500351951

Silva, J. M. C. S., \& Tenreyro, S. (2006). The log of gravity. The Review of Economics and Statistics, 88(4), 641-658. http://dx.doi.org/10.1162/rest.88.4.641

The Economist. (2004, October 2). The dragon and the eagle. A survey on the world economy. Retrieved from http://www.economist.com/sites/default/files/special-reports-pdfs/3219343.pdf 
Wang, C., Wei, Y., \& Liu, X. (2007). Does China rival its neighbouring economies for inward FDI? Transnational Corporations, 16(3), 35. Retrieved from http://unctad.org/en/Docs/iteiit20074a2_en.pdf

Wei, D. Y. (2008). Spatial data analysis of regional development in Greater Beijing, China, in a GIS environment. Papers in Regional Science, 87(1). http://dx.doi.org/10.1111/j.1435-5957.2007.00148.x

World Bank. (2013). World Bank Open Data. Retrieved from http://www.worldbank.org

Zhou, Y., \& Lall, S. (2005). The impact of China's FDI surge on FDI in South-East Asia: Panel data analysis for 1986-2001. Transnational Corporations, 14(1), 41-65. Retrieved from http://unctad.org/en/Docs/iteiit20051a2_en.pdf

\section{Note}

Note 1. For exceptions see Ianchovichina and Walmsley (2005), who calculate an computable general equilibrium (CGE) to predict the effect of China`s adhesion to the World Trade Organization (WTO).

\section{Copyrights}

Copyright for this article is retained by the author(s), with first publication rights granted to the journal.

This is an open-access article distributed under the terms and conditions of the Creative Commons Attribution license (http://creativecommons.org/licenses/by/3.0/). 